\title{
A Study on Knowledge Level of Ginger Growers on Improved Cultivation Practices in Hassan District, India
}

\author{
B. R. Sundresha, D. Nanjappa, R. Vinay Kumar* and M. T. Lakshmi Narayan \\ Department of Agricultural Extension, University of Agricultural Sciences, \\ Banglore-560 065, India \\ *Corresponding author
}

\begin{abstract}
A B S T R A C T
\section{Keywords}

Knowledge, Full

knowledge, Partial

knowledge,

Improved

cultivation practices

Article Info

Accepted:

22 June 2020

Available Online:

10 July 2020

The study was carried out in two taluks of Hassan district during 2017- 18 to study the knowledge and adoption of improved cultivation practices by ginger growers. A total of 80 ginger growers selected for the study as the respondents. Data was collected using a pre-tested interview schedule. The results revealed that majority of the ginger growers possessed high $(60.00$ $\%)$ level of knowledge about improved cultivation practices. Whereas, 21.25 and 18.75 per cent of the ginger growers belongs to medium and low knowledge categories, respectively. More than half $(53.75 \%)$ of the ginger growers belongs to high adoption category. Whereas, 25.00 and 21.25 per cent of the ginger growers belongs to medium and low adoption categories, respectively.
\end{abstract}

\section{Introduction}

The history of Indian spices dates back to the beginning of human civilization. There are over 50 species of spices cultivated in India and many of them are indigenous viz, Black Pepper, Cardamom, Ginger and Turmeric while Clove, Vanilla, Nutmeg and Chilli are introduced from other countries. Ginger (Zingiber officinale Rosc.) is fragrant spice made from the rhizome of a plant, which may be chopped or powdered for cooking, preserved in syrup, or candied and one of the important vegetable/ cash crops grown in India. It belongs to genus Zingiber under
Zingiberaceace family. According to Food and Agricultural Organization, the total Ginger production in the world is 20, 23, 113tonnes (Anonymous, 2011). India is the largest producer of Ginger in the world contributing $(34.60 \%)$ with a production of 702 thousand tonnes of the global production followed by China (19.10\%) with a production of 426.03 thousand tonnes, respectively.

The top five ginger producing countries are India, China, Nepal, Nigeria and Thailand. The total Ginger produced in the country was 7, 02, 000 tonnes from an area of 1, 49, 199 
ha with a productivity of $2,903 \mathrm{Kg}$ per ha. Hassan, Mysore, Kodagu, Shimoga and Bidar contribute over 70 per cent of the total production in Karnataka. Hassan has the highest area and production of 14,176 ha and 86,598 Metric tonnes respectively with the productivity of 6.11 metric tonnes (Anonymous, 2017). Several studies have been conducted on food crops to know the knowledge and adoption, but very few research studies have been conducted on spice crops. Recent studies have shown that there is a tremendous scope to increase the ginger yield and the fact is that all farmers are not getting the potential yield.

With this background, the study was undertaken with the following objectives includes to know the socio-economic profile of the ginger growers. To assess the knowledge level of the ginger growers regarding the improved cultivation practices. And also to find out the association between knowledge of ginger growers with their socioeconomic profile.

\section{Materials and Methods}

The study was conducted during 2017-2018 in Hassan district of Karnataka State. Hassan district was selected purposively, because it has more area under ginger in Karnataka. Hassan district has eight taluks, out of which Hassan and Arakalagud taluks were selected purposively considering the higher area and production.Four villages were randomly selected from each taluk and hence eight villages with high ginger area were selected.

The villages thus selected were Kudaluru, VosavadaHosahalli, Konapura and Chikkalli of Arakalagudtaluk; Somanahalli, Siddapura, Muthatthi and Konehalli from Hassan taluk.In the present investigation "Ex-post facto" research design was used. Expost-facto research design is defined as any systematic empirical inquiry in which the independent variables have not directly manipulated because they have already occurred or because they are inherently not manipable. The independent variables considered in the study have already occurred and are not directly manipulated by the type of variables under consideration, size of the respondents and the phenomenon to be studied. Hence, the selected design considered was appropriate.

Knowledge is operationally defined as "This refers to the body of information understood and retained by the ginger growers about the ginger cultivation as recommended in package of practices of University of Agricultural Sciences, Bengaluru'.Improved cultivation practices are operationalized as the practices of ginger management are envisaged in the book of package of practices recommended by the University of Agricultural Sciences, Bengaluru.

The "Teacher made test" suggested by Anastasi (1961) was employed to measure the knowledge level of respondents. All the important operations of ginger cultivation were listed in consultation with the experts. Total numbers of twenty-nine important recommended practices were selected. The questions and answers were carefully formed. The answers elicited from the farmers were quantified by giving scores.

The knowledge test developed was administered to the respondents. Quantification of the knowledge item answers were made by giving two score (full knowledge), one score (partial knowledge) and zero score (no knowledge) for most appropriate, appropriate and less appropriate answers respectively. The scores of entire individual items were summed to get the knowledge score of respondents. The maximum score one could get was 58 and minimum was zero. 


\section{Results and Discussion}

\section{Profile of the farmers selected for the study}

Slightly more than half $(53.75 \%)$ of the respondents belonged to middle aged category followed by old age $(23.75 \%)$ and young age category $(22.50 \%)$.With regard to the literacy level, more than one-fourth $(26.25 \%)$ of the respondents had completed above graduation followed by illiterates $(25.00 \%)$ and primary schooling (25.00\%), high schooling (12.50 $\%)$ and only 6.25 per cent had completed middle school education. Surprisingly, small fraction $(5.00 \%)$ proportion of the respondents had PUC. Regarding land holding, 40.00 per cent respondents were small farmers, followed by marginal farmers $(28.75 \%)$, medium farmers $(22.50 \%)$ and very less $(8.75 \%)$ big farmers. It implies that small farmers had knowledge about improved cultivation of ginger and had adopted such practices in its cultivation. With respect to annual income, majority of the farmers belonged to medium level of income (51.25 $\%)$ followed by high level (33.75\%) and low $(15.00 \%)$ annual income groups. Half (50.00 $\%$ ) of respondents belonged to high level of farming experience category followed by medium $(37.50 \%)$ and low $(12.00 \%)$ level of farming experience respectively. Nearly three fourth $(73.75 \%)$ of the respondents belonged to medium level of achievement motivation category followed by 16.25 per cent of farmers who had low and 10.00 per cent who had high level of achievement motivation. About 47.50 per cent of respondents belonged to high category of economic motivation, while 32.50 and 20.00 per cent of the respondents belonged to medium and low economic motivation category, respectively. Fifty per cent of the respondents belonged to high level of risk orientation category followed by each of 25 per cent of farmers with low and medium level of risk orientation. A greater proportion $(61.25 \%)$ of respondents belonged to high level of management orientation category followed by 20.00 per cent who belonged to medium and 18.75 per cent in low level management of orientation category, respectively. Nearly two third $(62.50 \%)$ of the respondents had medium level of cosmopoliteness followed by high level $(30.00 \%)$ and 07.50 per cent with low level of cosmopoliteness. Nearly half $(48.75 \%)$ of the respondents belonged to high level of social participation followed by medium $(46.25 \%)$ and low $(05.00 \%)$ level of social participation. As far as mass media exposure is concerned, fifty per cent of the farmers belonged to high mass media exposure category followed by high and low level of mass media exposure category 25.00 $\%$ each. Nearly half $(46.25 \%)$ of the respondents belonged to high extension contact category followed by 30.00 per cent in medium and 23.75 per cent in low level of extension contact category, respectively. More than one third $(36.25 \%)$ of the ginger growers belonged to medium category of extension participation followed by high $(35.00 \%)$ and low $(28.75 \%)$ category. The results obtained may be due to interest of respondents in solving their problems with extension workers, also interest in extension activities to gather recent information and to learn about practical utility of the new technology from extension workers. The present study results are in line with the findings of Yashaswini (2013), Sahana (2002) and Nagesha (2005).

Practice-wise knowledge of ginger growers about improved cultivation practices in ginger

The Table 2 reveals the Cent per cent of ginger growers had full knowledge about practices like cultivation of recommended varieties and raised bed method of ginger cultivation. Majority of the ginger growers $(60.00,62.50,62.50,76.25,77.50,87.50$, 
$87.50,88.75,90.00,92.50,95.00,97.50$, $97.50,98.75 \%)$ had full knowledge on application of recommended dose of phosphorous and potash top dressing of fifty per cent of nitrogen 30 days and 60 days after planting, control of shoot borer, application of $\mathrm{N}: \mathrm{P}: \mathrm{K}$ fertilizer, control of soft rot, weekly irrigation, control of leaf spot, optimum spacing, appropriate time of harvesting, planting time, curing, pre-ploughing and FYM application, respectively. Majority of ginger growers $(66.25 \%)$ had partial knowledge on appropriate weight of rhizome used for planting and a majority (87.50, $73.75,61.25 \%$ ) had no knowledge on storage of the produce, grading and certification and mancozeb usage for seed treatment respectively. All the ginger growers had full knowledge on cultivation of recommended varieties and raised bed method for ginger cultivation. The reason was most of the farmers were well educated and they had good extension agency contact. The ginger growers were also aware that good yield of the crop mainly depends on selection of varieties. Majority of the ginger growers had full knowledge on time of planting, usage of recommended quantity of rhizome for sowing, optimum spacing, number of preploughings etc. The main reasons were most of the ginger growers start sowing the crop immediately monsoon starts and also another reason might be more exposure to various training programmes, awareness programmes, demonstration and Krishi mela. All these factors might have influenced the respondents to acquire more knowledge. Most of the ginger growers had partial knowledge on usage of recommended weight of single rhizome. The reason was farmers are in the persuasion that usage of big rhizome yields more. Majority of the ginger growers had full knowledge on application of recommended dose of manures and fertilizers, hand weeding, providing irrigation, mulching, earthing up, appropriate time of harvesting and potential yield of ginger. The main reason was, if the individual is having higher education, high extension contact, more farming experience with higher income naturally, one would like to have more knowledge about new technologies and would like to earn more profit.

\section{Overall knowledge of Ginger growers on improved cultivation practices}

The data in Table 3reveals little less than two third $(60.00 \%)$ of the respondents belonged to higher category group of knowledge in improved cultivation practices of ginger followed by medium category $(21.25 \%)$ and low category $(18.75 \%)$ of knowledge level, respectively. The gain in higher knowledge might be due to majority of the ginger growers were educated and they were able to gain information regarding improved ginger cultivation practices with the support from agricultural related institutions. The probable reasons for this may be that the farmers practicing ginger cultivation who had medium achievement motivation and cosmopoliteness as well as high level of management orientation and mass media exposure also had high farming experience. The findings are in conformity with the findings of Kanavi (2000).

\section{Association between independent variables and knowledge of ginger growers}

The data in Table 4reveals that education, achievement motivation, risk orientation, cosmopoliteness, economic motivation and mass media participation were significantly and positively associated to their extent of knowledge of ginger growers at 5 per cent level and management orientation, extension contact and extension participation were significant at 1 per cent level. The findings are in conformity with the findings of Kanavi (2000). 
Table.1 Profile of the farmers selected for the study

\begin{tabular}{|c|c|c|c|c|}
\hline \multirow[t]{2}{*}{ Sl. No } & \multirow[t]{2}{*}{ Characteristics } & \multirow[t]{2}{*}{ Category } & \multicolumn{2}{|c|}{ Ginger growers } \\
\hline & & & Frequency & $\%$ \\
\hline \multirow[t]{3}{*}{1} & \multirow[t]{3}{*}{ Age } & Young (<35 years) & 18 & 22.50 \\
\hline & & Middle (35-50 years) & 43 & 53.75 \\
\hline & & Old $(>50$ years $)$ & 19 & 23.75 \\
\hline \multirow[t]{6}{*}{2} & \multirow[t]{6}{*}{ Education } & Illiterate & 20 & 25.00 \\
\hline & & Primary & 21 & 25.00 \\
\hline & & Middle school & 05 & 06.25 \\
\hline & & High school & 10 & 12.50 \\
\hline & & PUC & 04 & 05.00 \\
\hline & & Graduation and above & 20 & 26.25 \\
\hline \multirow[t]{4}{*}{3} & \multirow[t]{4}{*}{ Land holding } & Marginal farmers (up to 2.5 acres) & 23 & 28.75 \\
\hline & & Small farmers (2.51 to 5.00 acres) & 32 & 40.00 \\
\hline & & Medium farmers (5.01 TO 10.00 acres) & 18 & 22.50 \\
\hline & & Big farmers $(>10.01$ acres $)$ & 07 & 08.75 \\
\hline \multirow[t]{3}{*}{4} & \multirow[t]{3}{*}{ Annual income } & Low (< Rs.1 lakh) & 12 & 15.00 \\
\hline & & Medium ( 1 to 3 lakh) & 41 & 51.25 \\
\hline & & High (>3 lakh) & 27 & 33.75 \\
\hline \multirow[t]{3}{*}{5} & \multirow{3}{*}{$\begin{array}{l}\text { Extension contact } \\
\text { Mean }=14.40 \\
\text { S.D }=2.40\end{array}$} & Low & 19 & 23.75 \\
\hline & & Medium & 24 & 30.00 \\
\hline & & High & 37 & 46.25 \\
\hline \multirow[t]{3}{*}{6} & \multirow{3}{*}{$\begin{array}{l}\text { Extension participation } \\
\text { Mean }=20.20 \\
\text { S.D }=1.90\end{array}$} & Low & 23 & 28.75 \\
\hline & & Medium & 29 & 36.25 \\
\hline & & High & 28 & 35.00 \\
\hline \multirow[t]{3}{*}{7} & \multirow{3}{*}{$\begin{array}{l}\text { Risk orientation } \\
\text { Mean }=22.40 \\
\text { S.D }=2.44\end{array}$} & Low & 20 & 25.00 \\
\hline & & Medium & 20 & 25.00 \\
\hline & & High & 40 & 50.00 \\
\hline \multirow[t]{3}{*}{8} & \multirow{3}{*}{$\begin{array}{l}\text { Achievement motivation } \\
\text { Mean }=21.60 \\
\text { S.D }=2.40\end{array}$} & Low & 13 & 16.25 \\
\hline & & Medium & 59 & 73.75 \\
\hline & & High & 8 & 10.00 \\
\hline \multirow[t]{3}{*}{9} & \multirow[t]{3}{*}{ Farming experience } & Less $(<10$ years $)$ & 10 & 12.50 \\
\hline & & Moderate(10-20 years) & 30 & 37.50 \\
\hline & & More(>20 years) & 40 & 50.00 \\
\hline \multirow[t]{3}{*}{10} & Social participation & Low & 37 & 46.25 \\
\hline & Mean $=16.96$ & Medium & 4 & 05.00 \\
\hline & S.D $=1.77$ & High & 39 & 48.75 \\
\hline 11 & Economic motivation & Low & 16 & 20.00 \\
\hline & Mean $=20.04$ & Medium & 26 & 32.50 \\
\hline & S.D $=2.45$ & High & 38 & 47.50 \\
\hline 12 & Cosmopoliteness & Low & 06 & 07.50 \\
\hline & Mean $=22.10$ & Medium & 50 & 62.50 \\
\hline & S.D $=2.44$ & High & 24 & 30.00 \\
\hline 13 & Mass media & Low & 20 & 25.00 \\
\hline & participation & Medium & 20 & 25.00 \\
\hline & $\begin{array}{l}\text { Mean }=9.20 \\
\text { S.D }=1.56\end{array}$ & High & 40 & 50.00 \\
\hline 14 & Management orientation & Low & 15 & 18.75 \\
\hline & Mean $=24.40$ & Medium & 16 & 20.00 \\
\hline & S.D $=2.40$ & High & 49 & 61.25 \\
\hline
\end{tabular}


Table.2 Practice-wise knowledge of ginger growers about improved cultivation practices in ginger

\begin{tabular}{|c|c|c|c|c|c|c|c|}
\hline \multirow{3}{*}{$\begin{array}{l}\text { Sl. } \\
\text { No. }\end{array}$} & \multirow{3}{*}{ Components of improved cultivation practices } & \multicolumn{6}{|c|}{ Knowledge level } \\
\hline & & \multicolumn{2}{|c|}{$\begin{array}{c}\text { Full } \\
\text { Knowledge }\end{array}$} & \multicolumn{2}{|c|}{$\begin{array}{c}\text { Partial } \\
\text { Knowledge }\end{array}$} & \multicolumn{2}{|c|}{$\begin{array}{c}\text { No } \\
\text { Knowledge }\end{array}$} \\
\hline & & No. & $\%$ & No. & $\%$ & No. & $\%$ \\
\hline 1 & Cultivation of recommended varieties & 80 & 100.00 & 00 & 00.00 & 00 & 00.00 \\
\hline 2 & Time of planting (May- June) & 76 & 95.00 & 00 & 00.00 & 04 & 05.00 \\
\hline 3 & Appropriate weight of seed material (Rhizome) & 15 & 18.75 & 53 & 66.25 & 12 & 15.00 \\
\hline 4 & $\begin{array}{l}\text { Use of Mancozeb and quinalphos for seed } \\
\text { treatment }\end{array}$ & 05 & 06.25 & 26 & 32.50 & 49 & 61.25 \\
\hline 5 & $\begin{array}{l}\text { Usage of recommended quantity of rhizome per } \\
\text { acre }(600 \mathrm{~kg})\end{array}$ & 45 & 56.25 & 26 & 32.50 & 09 & 11.25 \\
\hline 6 & Raised bed method for cultivation of Ginger & 80 & 100.00 & 00 & 00.00 & 00 & 00.00 \\
\hline 7 & Optimum spacing $(30$ X $15 \mathrm{~cm}$ ) for cultivation & 72 & 90.00 & 08 & 10.00 & 00 & 00.00 \\
\hline 8 & Four pre-ploughings in land preparation & 78 & 97.50 & 02 & 02.50 & 00 & 00.00 \\
\hline 9 & 10 MT FYM application & 79 & 98.75 & 01 & 01.25 & 00 & 00.00 \\
\hline 10 & $\begin{array}{l}\text { Application of fertilizer NPK (40:20:20 Kg per } \\
\text { acre) for cultivation }\end{array}$ & 62 & 77.50 & 18 & 22.50 & 00 & 00.00 \\
\hline 11 & $\begin{array}{l}\text { Application of recommended dose of fertilizers in } 3 \\
\text { splits }\end{array}$ & 46 & 57.50 & 25 & 31.25 & 09 & 11.25 \\
\hline 12 & $\begin{array}{l}\text { Top dressing of } 50 \text { per cent nitrogen fertilizer after } \\
30 \text { days }\end{array}$ & 50 & 62.50 & 00 & 00.00 & 30 & 37.50 \\
\hline 13 & $\begin{array}{l}\text { Top dressing of remaining } 50 \text { per cent nitrogen } \\
\text { fertilizer after } 60 \text { days }\end{array}$ & 50 & 62.50 & 00 & 00.00 & 30 & 37.50 \\
\hline 14 & $\begin{array}{l}\text { Application of recommended dose of phosphorous } \\
\text { and potash at the time of planting }\end{array}$ & 48 & 60.00 & 24 & 30.00 & 08 & 10.00 \\
\hline 15 & Providing irrigation weekly & 70 & 87.50 & 10 & 12.50 & 00 & 00.00 \\
\hline 16 & Hand weeding & 70 & 87.50 & 10 & 12.50 & 00 & 00.00 \\
\hline 17 & Crop rotation & 41 & 51.25 & 00 & 00.00 & 39 & 48.75 \\
\hline 18 & Mulching three times & 46 & 57.50 & 28 & 35.00 & 06 & 07.50 \\
\hline 19 & Earthing up at 45 and 90 days after planting & 36 & 45.00 & 25 & 31.25 & 19 & 23.75 \\
\hline 20 & Appropriate time of harvesting & 74 & 92.50 & 06 & 07.50 & 00 & 00.00 \\
\hline \multirow[t]{8}{*}{21} & Plant protection measures & & & & & & \\
\hline & a) Pests & & & & & & \\
\hline & $\begin{array}{l}\text { i. Quinalphos @ } 0.075 \% \text { to control Rhizome } \\
\text { Scale }\end{array}$ & 41 & 51.25 & 32 & 40.00 & 07 & 08.75 \\
\hline & ii. Malathion@ @ $0.1 \%$ to control shoot borer & 61 & 76.25 & 13 & 16.25 & 06 & 07.50 \\
\hline & b) Diseases & & & & & & \\
\hline & i. Mancozeb @ $0.125 \%$ to control soft rot & 70 & 87.50 & 05 & 06.25 & 05 & 06.25 \\
\hline & ii. Carbendazim @ $0.2 \%$ to control leaf spot & 71 & 88.75 & 06 & 07.50 & 03 & 03.75 \\
\hline & $\begin{array}{l}\text { iii. Streptomycin@ } 200 \text { ppm to control bacterial } \\
\text { wilt }\end{array}$ & 41 & 51.25 & 24 & 30.00 & 15 & 18.75 \\
\hline 22 & Potential yield of ginger crop (15-20 MT) & 36 & 45.00 & 18 & 22.50 & 26 & 32.50 \\
\hline \multirow[t]{4}{*}{23} & Post-Harvest Management & & & & & & \\
\hline & a.Curing of ginger after harvesting & 80 & 100.00 & 00 & 00.00 & 00 & 00.00 \\
\hline & b.Storage of ginger & 21 & 26.25 & 00 & 00.00 & 59 & 73.75 \\
\hline & c.Grading and certification & 10 & 12.50 & 00 & 00.00 & 70 & 87.50 \\
\hline
\end{tabular}


Table.3 Overall knowledge of Ginger growers on improved cultivation practices

\begin{tabular}{|l|c|c|}
\hline \multicolumn{1}{|c|}{ Knowledge level } & Number & Per cent \\
\hline Low & 15 & 18.75 \\
\hline Medium & 17 & 21.25 \\
\hline High & 48 & 60.00 \\
\hline Total & 80 & 100.00 \\
\hline
\end{tabular}

Mean $=36.41 ;$ Standard deviation $=5.452$

Table.4 Association between independent variables and knowledge of ginger growers

\begin{tabular}{|c|l|c|c|}
\hline Sl. No. & \multicolumn{1}{|c|}{ Characteristics } & Chi-square value & Contingency Coefficient \\
\hline $\mathbf{1}$ & Age & $6.18 \mathrm{NS}$ & 0.18 \\
\hline $\mathbf{2}$ & Education & $12.23^{*}$ & 0.27 \\
\hline $\mathbf{3}$ & Land holding & $5.91 \mathrm{NS}$ & 0.16 \\
\hline $\mathbf{4}$ & Annual income & $6.99 \mathrm{NS}$ & 0.21 \\
\hline $\mathbf{5}$ & Farming experience & $7.98 \mathrm{NS}$ & 0.22 \\
\hline $\mathbf{6}$ & Achievement motivation & $9.97^{*}$ & 0.27 \\
\hline $\mathbf{7}$ & Management orientation & $12.10^{* *}$ & 0.28 \\
\hline $\mathbf{8}$ & Risk orientation & $11.61^{*}$ & 0.29 \\
\hline $\mathbf{9}$ & Cosmopoliteness & $10.99^{*}$ & 0.27 \\
\hline $\mathbf{1 0}$ & Economic motivation & $12.99^{*}$ & 0.31 \\
\hline $\mathbf{1 1}$ & Social participation & $7.16 \mathrm{NS}$ & 0.25 \\
\hline $\mathbf{1 2}$ & Mass media participation & $9.26^{*}$ & 0.26 \\
\hline $\mathbf{1 3}$ & Extension contact & $14.68^{* *}$ & 0.32 \\
\hline $\mathbf{1 4}$ & Extension participation & $15.99^{* *}$ & 0.33 \\
\hline * Significant@5\% level **Significant @ 1\% level & NS-Non significant \\
\hline
\end{tabular}

In conclusion the majority of the respondents lacked knowledge about storage, grading and certification and also not adopted these practices. Hence, it is crucial that the Developmental Departments, NGOs, State Agricultural universities and Spice Board to make integrated efforts in educating the farmers regarding modern and useful technologies to enrich their knowledge and make them to adopt post-harvest technologies. However, presently most of the farmers were not practicing any of the postharvest technologies and they were selling the produce immediately after the harvesting.

\section{References}

Anastasi.A., 1961, Physiological testing. M. Sc. (Agri.) Thesis, Millen and Co., New York.,3(4): 420-435.

Anonymous., 2011, Food and Agricultural Organisation Corporate Statistical Database, FAO, Rome.

Anonymous., 2017, Horticultural statistics at a glance, Annual report, Government of India, 19(5):12-24.

Kanavi, V. P., 2000, A study on the knowledge and adoption behaviour of Sugarcane growers in Belgaum district of Karnataka. M. Sc. (Agri.) Thesis, 
Univ. Agric. Sci., Dharwad.

Nagesha, 2005, Study on entrepreneurial behaviour of vegetable seed producing farmers in Haveri district of Karnataka. M. Sc. (Agri.) Thesis, Univ. Agric. Sci., Bangalore.

Sahana, S., 2002 Study about the functioning of Raitha Samparka Kendra. M. Sc.
(Agri), Thesis, Univ. Agric. Sci., Bangalore.

Yashashwini, M. A., 2013, Effectiveness of front line demonstrations of KrishiVigyana Kendra on FLD Farmers of Mandya district, M. Sc. (Agri.) Thesis, Univ. Agric. Sci., Bangalore.

\section{How to cite this article:}

Sundresha, B. R., D. Nanjappa, R. Vinay Kumar and Lakshmi Narayan, M. T. 2020. A Study on Knowledge Level of Ginger Growers on Improved Cultivation Practices in Hassan District, India. Int.J.Curr.Microbiol.App.Sci. 9(07): 3014-3021.

doi: https://doi.org/10.20546/ijcmas.2020.907.354 